\title{
What Will Happen to Retirement Economy in the Baltic States?
}

\author{
Olga Pavuk \\ Department of Regional Economy and Economic Policy, Baltic International Academy, Latvia
}

Copyright $(2016$ by authors, all rights reserved. Authors agree that this article remains permanently open access under the terms of the Creative Commons Attribution License 4.0 international License.

\begin{abstract}
The new term "retirement economy", as no other one, characterises realities not only of the modern labour market, but also of the world economy. The adverse demographic situation in the Baltic States allows speaking about the inability of the present retirement system for future pensioners. Besides low birth rate it is necessary to mention substantial out-migration of able-bodied population to other countries with good working opportunities. The adverse demographic situation and labour migration are the basis of pessimism and non-confidence of the population, especially of the youth, in the state retirement system. People understand that if at the moment of their retirement in the country there is not enough labour force, and the number of young people has been reduced, it will not be possible to resolve the issue of decent pensions. The raising of retirement age will hardly help to make a difference. Aging of the population on the European continent in general and Latvia in particular leads to increase in demographic loading. The share of aged population in the national economy increases quicklier than the inflow of young and middle-aged population, i.e. persons who are at the age of labour activity. The immigration flow accruing from year to year also has a negative impact on a qualitative structure and number of labour forces. One of solutions could be a paradoxical decision to lower retirement age. In order to free up jobs for young people, particularly keenly felt the burden of unemployment and to motivate them to participate in social programs and pension funds.
\end{abstract}

Keywords Retirement Economy, Virtualization, Employment, Demography

JEL J26, J60, O32

\section{Introduction}

The first state pensions appeared in Germany under the rule of "the Iron Chancellor", Bismarck, in 1889. They were paid to workers who reached the age of 70 years, but at the time average life expectancy was only 45 years. In other developed countries the Old Age Pension appeared only in the 20th century. A little more than 100 years passed, and today with ever increasing frequency, it is said that there is a crisis of the state retirement system. Actually, a new term "retirement economy" has emerged.

The term "retirement economy", as no other one, characterises realities not only of the modern labour market, but also of the world economy. In the "retirement" economy growth is obviously weak and incapable to support full employment as it is focused not on growth, but on consumption as Alexei Mikhailov, an expert at the Center of Economic and Political Research (EPI center) ${ }^{[1]}$, writes. It is one of the new principles of economic performance which has not been understood / embraced by economic science and practice yet.

The world economy grows old in line with the rise in life expectancy of the population, which is especially characteristic of developed countries, namely they form the basis of the national and world economy. Many worldwide researchers note a tendency of population ageing concurrently with rising unemployment. "Population ageing exercises a decisive influence over the economy. Many trends develop, accumulate and eventually lead to the crisis, which has to change the principle of performance of economic system", A.Mikhailov considers.

Empirical research shows that it occurs when the national median age (half the population is older, the other half is younger) is 35 - 40 years. The national requirements to economy change with ageing. If the "new" economy is ready to work and put away money for the future, the "old" economy inclines to start spending that has earlier been saved. It is necessary to manage to use that has been saved up while there is health. The "old" economy sharply increases the tendency to consumption.

According to "The World Development Report 2013" by the World Bank, about 200 million people cannot find work,

1 Mikhailov A. "Pensionnaja" ekonomika diktuet. On-line newspaper gazeta.ru [Internet]. 2013 [cited 2013 Jan 2]. Available from: http://www.gazeta.ru/column/mikhailov/4911557.shtml 
one third is younger than $25^{[2]}$. At the same time in many countries retirement age is raised. There is a contradiction and its resolution is worthy of the Nobel Prize in Economics.

One of the arguments of the supporters of raising the retirement age is the rise in life expectancy of the population connected with the improvement of health treatment, health promotion in all of its aspects. Indeed, many people in developed countries keep performance capability much longer; they are ready to continue employment.

Another argument is absolutely different and connected with a lack of social security means for payment of decent pensions because of decline in birth rate and, respectively, reduction of the labour force. It is particularly felt in many countries with anaemic or emerging economy and where the invisible economy reigns.

The demographic crisis has affected many western countries, including developed ones. However, owing to maturity of economy in developed countries, issues of social security are not particularly pointed there in comparison with the new European countries. But the Old Country also worries about the provision of decent pensions to the next generations.

In fact, in the work "The life-cycle hypothesis and intercountry differences in the saving ratio", published in 1966, one of Nobel Prize winners in economics, Franco Modigliani, used the life cycle hypothesis of saving in the long-term plan for testing of alternative retirement plans. Modigliani proved that saving was closely connected with the growth rate of the population as this rate influenced the ratio of young and retired people to labour force $\mathrm{e}^{[3]}$.

\section{The Demographic Crisis in the Baltic Countries}

But today we will speak about that is closer to us, i.e. about the Baltic countries, where the demographic crisis is particularly pointed. Demographers speak about unattractive prospects but some of them even predict terms of extinction of the nation-state. "If in the next three - five years "demographic breakthrough" is not reached, the situation threatens to become irreversible as Latvia will get into the "demographic hole" soon, and the number of women of fertile age will sharply decrease" Latvian demographer Ilmars Mezhs ${ }^{[4]}$ says. I.Mezhs assumes that in only one generation the number of Latvians becomes less than the number of Estonians. Now the hope of the state is people at the age of $25-35$ without children or with one child. If not to

\footnotetext{
${ }^{2}$ World Bank. World Development Report 2013: Jobs. Washington, DC. C World Bank [Internet]. 2012 [cited 2013 Jan 2]. Available from: http://siteresources.worldbank.org/EXTNWDR2013/Resources/8258024-1 320950747192/8260293 1322665883147/Overview_Russian.pdf

${ }^{3}$ Modigliani F. The life-cycle hypothesis and intercountry differences in the saving ratio. In: Eltis W. A., Scott M. FG., and Wolfe J. N., editors Induction, growth, and trade:essays in honour of Sir Roy Harrod. Oxford: Oxford University Press; 1970. p. 197-225.

${ }^{4}$ Mezhs I. Children - Latvian strategic capital. Kapitāls. 2011 February.
}

motivate this generation to family foundation and parity progression, in 2050 - 2060 the number of immigrants in Latvia will be compared to the number of the local population, but in 100 years the number of descendants of the local community will be less than half a million as the demographer believes. This problem especially concerns the ruling politicians.

Among the Baltic countries the most adverse demographic situation is in Latvia, where the ratio of elderly people (over 65 years old) to labour force (aged from 15 till 64 years old) is the largest $(28 \%)$. Demographic projections say that by 2040 in Latvia this ratio will have reached $43 \%$. However, the projections are not less disturbing for Lithuania and Estonia as in these countries the dependency ratio can reach $42 \%$ and $40 \%$ respectively.

In the middle of the first decade of the 21 st century the projections of the Latvian demographers were much more optimistic than they actually appeared. Thus, in 2005 the famous demographer, professor P. Zvidrinsh predicted that by 2010 - 2015 the population of Latvia would have been reduced from 2,32 million to 2,17 - 2,07 million people, and by 2050 - to 1,87 million. Similar projections were given by the UN, Eurostat and scientists of the Latvian University. They predicted reduction of the Latvian population to 1,6 1,7 million people by $2050^{[5]}$.

In fact, in 2011 the census enumeration already showed that the number of inhabitants in the country had fallen to 2 million and was continuing to decrease. According to the research of the Population Reference Bureau (the USA) carried out in 200 countries, Latvia as well as Taiwan is rated to the countries with the lowest birth rate $(1,1)$. In top 10 rating of the countries with the lowest birth rate there are Singapore, Bosnia-Herzegovina, South Korea, Hungary $(1,2)$ and Moldova, Poland, Romania, Portugal $(1,3)$. The highest birth rate is in Nigeria $(7,1)$. According to the projections of the researchers by 2050 the Latvian population in comparison with 2010 will have been reduced by $19,8 \%$ or to 1,8 million inhabitants ${ }^{[6]}$.

Table 1. Population in the Baltic countries, million

\begin{tabular}{|c|c|c|c|}
\hline & 2012 & 2025 & $2050^{*}$ \\
\hline Estonia & 1,3 & 1,3 & 1,2 \\
\hline Latvia & 2,0 & 1,9 & 1,6 \\
\hline Lithuania & 3,2 & 3,0 & 2,7 \\
\hline
\end{tabular}

* The estimation of World population Data Sheet. 50 Years. 1962 - 2012. Population Reference Bureau.

According to P.Zvidrinsh's projections, under the general decline of the Latvian population life expectancy will grow. By 2050 it is expected that the average age of women will

\footnotetext{
5 World population Data Sheet. 50 Years. 1962-2012. Population Reference Bureau [Internet]. 2012 [cited 2013 Jan 3]. Available from: http://www.prb.org/pdf12/2012-population-data-sheet_eng.pdf

6 World population Data Sheet. 50 Years. 1962-2012. Population Reference Bureau. [Internet]. 2012 [cited 2013 Jan 3]. Available from: http://www.prb.org/pdf12/2012-population-data-sheet_eng.pdf
} 
have been 82 , and men - 74. At the same time, labour force will have reduced from 1,6 million in 2005 to 1 million in 2050 , and the number of inhabitants at the age of $65+$ will have increased from 381 to 493 thousand people. Ratio of persons who attained pension age will increase from $16,5 \%$ in 2005 to $26-29 \%$ in $2051^{[7]}$.

According to the projections of the edition of "'Demografija ir MES', at the end of the century inhabitants of Lithuania aged 65 and older could also have made $40 \%$ of the entire population (about $18 \%$ at the present moment). That is, even if the birth rate starts improving, population ageing will proceed in any case. Even the decline in migration will not increase growth rate of the population as a whole ${ }^{[8]}$.

Besides low birth rate it is necessary to mention substantial out-migration of able-bodied population to other countries with good working opportunities. According to University of Latvia professor M. Hazan's estimates, since 2000 not less than 300 thousand people have left Latvia, and rates of migration of labour force remain at the same level ${ }^{[9]}$. In the recent research of the Latvian University and the Institute for the Study of Labour IZA (Germany) it has been noted that migration significantly contributed to decline in unemployment in Latvia ${ }^{[10]}$. It became even more noticeable in 2010 - 2011 when the direct impact of labour migration on the unemployment rate increased. That is without the increase in migration the situation on the labour market of Latvia could be even worse.

The adverse demographic situation and labour migration are the basis of pessimism and non-confidence of the population, especially of the youth, in the state retirement system. The situation with payment of the social tax is good only at government agencies and enterprises, and at large foreign companies. Small and medium-sized businesses are by half in the invisible economy. People understand that if at the moment of their retirement in the country there is not enough labour force, and the number of young people has been reduced, it will not be possible to resolve the issue of decent pensions. The raising of retirement age will hardly help to make a difference.

\section{Retirement Pensions and Wages in the Baltic States}

However, the retirement age is raised in the majority of

\footnotetext{
${ }^{7}$ Peteris Z. The prognose of Latvian residents number and age structure. Demographic trends of Latvia in 21st century. Commission of Strategic Analysis. Scientific research articles. Riga: Zinatne;2006;3(9):164-187.

${ }^{8}$ Karalyunayte U. Nakopit na dostojnuju starost ne poluchitsja. Save up for a worthy old age will not work. [Internet]. 2013 [cited 2013 Apr 15]. Available from:

http://ru.delfi.lt/news/economy/nakopit-na-dostojnuyu-starost-ne-poluchits ya.d?id=61148709

Satvia. Human Development Report, 2010/2011. National identity, mobility and ability to function. Riga: Latvian University Faculty of Social and Political Research Institute; 2011. p.154.

${ }_{10}$ Latvia. Human Development Report, 2010/2011. National identity, mobility and ability to function. Riga: Latvian University Faculty of Social and Political Research Institute; 2011. p.154.
}

civilised countries. In Europe and the USA it is usual to retire at the age of 65; in some countries the retirement age for women is slightly lower. In developing economies, Russia and China the retirement age is lower, i.e. 55 - 60 years. In fact, recently the Russian president has declared that the retirement age in the country will not be raised. But that is not the issue of the Baltic countries, which were formerly a part of the USSR, but now as a part of the European Union they follow the "old" Europe. Not that long ago, in Latvia men and women retired at the age of 62 , but now the retirement age gradually increases until it reaches 65 . Estonians joke: "In Estonia our pension is as the skyline: the closer you are to it, the further it is from us".

In the Baltic countries the size of pensions leaves a great deal to be desired. To give a complete picture of the pension problem, let's use the data of the financial review of private households in the Baltic States conducted by the experts of SEB bank. It appeared that Lithuanians have the smallest pensions, but the most adverse demographic situation is in Latvia.

The average old-age pension in Lithuania in the 4th quarter of 2014 was 240 euros. In Latvia and Estonia the average old-age pension is 279 and 350 euros respectively. For example, in Latvia in $201253 \%$ of pensioners have 271-285 euros, and $24 \%$ - less than 214 euros. Please note that the minimum subsistence income in the country is 247 euros, i.e. three quarters of pensioners live on the breadline or below the poverty line.

Table 2. Retirement pensions and wages in the Baltic States, 2014

\begin{tabular}{|c|c|c|c|}
\hline Criteria & Estonia & Latvia & Lithuania \\
\hline $\begin{array}{c}\text { Average retirement pension, } \\
\text { EUR }\end{array}$ & 350 & 279 & 240 \\
\hline Average wage, EUR & 778 & 557 & 524 \\
\hline Minimum pay, EUR & 355 & 320 & 289 \\
\hline $\begin{array}{c}\text { Average life expectancy, } \\
\text { years }\end{array}$ & 74,7 & 72,2 & 72,1 \\
\hline Retirement age, years & 65 & 65 & 62,5 \\
\hline
\end{tabular}

The table is constituted by the author according to Eurostat data.

The size of retirement savings in relation to investments in Estonia increased from $25 \%$ in 2008 to $37 \%$ at the end of 2012, in Latvia - from 22 to $44 \%$, and in Lithuania - from 15 to $25 \%$. The contributions to the second pension pillar are larger than to the third one. The size of the second pillar pension savings per inhabitant is 1140 euros in Estonia, 720 euros in Latvia and 498 euros in Lithuania. In Latvia 1,2 million people or practically all taxpayers of the country have entered into the second pension pillar. $18 \%$ of all taxpayers have entered into the third pension pillar ${ }^{[11]}$.

\footnotetext{
11 Pavuk O. Pensionnie fondi Latvii gotovi $\mathrm{k}$ perehodu na evro. Pension funds in Latvia are ready to adopt the euro. Baltic-Course.com [Internet]. 2013 [cited 2013 Apr 15]. Available from:

http://www.baltic-course.com/rus/ analytics/?doc $=73292$
} 


\section{Criteria of the Labour Market in Latvia}

In order to get a more complete idea of the labour market in the light of the pension fund scheme, let's give another example. According to Central Statistical Bureau of the Republic of Latvia, the number of pensioners in the country in the first half of 2015 constituted 568 thousand people, including 473 thousand people receiving old-age pensions, approximately as many as in 2014. Using the data of Table 2 it is possible to calculate that today every employed person supports 1,8 old-age pensioner, besides there are disabled people and other categories of pensioners. It is necessary to notice that nearly a half of pensioners (230 thousand people) continue to work, mainly because in 2014 the average retirement pension in the country constituted 240 euros (in $2015-270$ euros) subtracting $21 \%$ of the income tax.

Table 3. Some criteria of the labour market in Latvia, thousands

\begin{tabular}{|c|c|c|c|}
\hline Criteria & 2012 & 2013 & 2014 \\
\hline Population, total & 2041,7 & 2003,4 & 1967,2 \\
\hline $\begin{array}{c}\text { Economically active } \\
\text { population }\end{array}$ & 1030,7 & 1014,2 & 992,3 \\
\hline $\begin{array}{c}\text { Employed in the national } \\
\text { economy }\end{array}$ & 875,6 & 893,9 & 884,6 \\
\hline Retirement pension recipients & 482,1 & 476,6 & 473,1 \\
\hline
\end{tabular}

The table is constituted by the author according to csb.lv

The population of Latvia is promptly reducing. If in the first year of independence, in 1991, in Latvia there were more than 2,6 million people, in 2014 the psychological threshold was reached: the population was less than 2 million, and the tendency of recession proceeds. Eurostat predicts that by 2050 the population of Latvia will have reduced to 1,45 million people. On the one hand, the population is growing old, according to forecasts of demographic analysts, by 2050 average life expectancy will have increased by 9 years (today it is 72,2 years, and it is one of the lowest indicators in the EU) ${ }^{[12]}$, and it is good. After multi-year reduction, the birth rate has started to slightly grow, and it is good too. On the other hand, after opening of borders for labour power in the EU, we can observe a substantial outflow of the population abroad, generally, there are youth and middle-aged people. In the estimation of Economist M. $\operatorname{Hazan}^{[13]}$, as a result of the international emigration in $2000-$ 2014 Latvia lost 260 thousand people. The assessment of the Central Statistical Bureau (246 thousand people) is very similar to the scientist's figures, and the tendency will remain in subsequent periods. Thereby, in the country it is possible to expect reduction of able-bodied population that provides the social budget.

\footnotetext{
${ }^{12}$ United Nations Development Programme. Life Expectancy Index 2014. Available from: http://hdr.undp.org/

${ }_{3}$ Latvijas emigrantu kopienas: cerību diaspora. Latvijas emigrantu kopienas: cerību diaspora. Emigrant communities of Latvia: diaspora of hope. In: Mierina I. Riga: LU; 2015. p. 236-20.
}

Aging of the population on the European continent in general and Latvia in particular leads to increase in demographic loading. The share of aged population in the national economy increases quicklier than the inflow of young and middle-aged population, i.e. persons who are at the age of labour activity. The immigration flow accruing from year to year also has a negative impact on a qualitative structure and number of labour forces.

One of the solutions for Latvia could be the paradoxical decision to lower retirement age, to give the chance to people if they do not want or cannot work, to retire earlier. It is quite likely that in a short time we will be forced to abandon the state retirement pensions for the majority of able-bodied population, having kept private pension funds and employers' contribution.

However, private pension funds in Latvia are still low-rated. About 2 billion euros from the budget of Latvia were spent on state pensions in 2014. At the same time the equity of private pension funds in 2014 was 280,7 million euros, but individual retirement accumulations constituted 14,6 million euros. A noteworthy detail is that in 2015 accumulations slightly decreased. 235 thousand people (77\% of individual participants and $23 \%$ of employees whose contributions are paid by employers) participate in the third pension pillar. This indicator increases every year, but growth rates are low. Individuals continue to use private pension funds as an alternative to other types of financial instruments. In 2014 in Latvia there were 6 private pension funds (5 open and 1 closed) offering 18 different pension plans $^{[14]}$.

In the opinion of the author, it is possible to heighten interest in private pension funds if state administration bodies give an opportunity to the employees to make retirement accumulations as an element of an additional salary. It is true that the employees in the sphere of state administration and municipalities are the most sustainable part of the labour market, and, therefore, they are potential participants of private pension funds. In general, according to our estimates, in the Latvian public sector there are about $35 \%$ of all employees. To this percentage it is possible to add the number of the employees of the state-owned enterprises and partially owned by the state and municipalities, such as Latvijas Dzelzcelš (11 thousand people), Rīgas austrumu klīniska universitātes slimnīca $(4,8)$, Latvenergo $(1,4)$, Lattelecom $(1,3)$, Latvijas meži $(1,2)$, airBaltic $(1,0)$, etc. (The Lursoft data for 2013). At the same time the majority of private enterprises and their employees are little interested in the third pension pillar. There are some explanations to this issue.

The first: the problem of the Latvian labour market is that in the country the middle class is only forming, and so far it has not substantially been involved in Defined Contribution Pension Systems. If to look at the structure of the Latvian

\footnotetext{
${ }^{14}$ Pensiju fondu apskats. Riga: Komercbanku associācija; 2014(12). Available from: http://lka.org.lv/lv/pdf/PFA_2014_gads_4_cet.pdf
} 
enterprises in general, we can see that small and medium-sized enterprises constitute $99,6 \%$ of all commercial structures ${ }^{[15]}$.

Table 4. Business Environment in Latvia, 2013

\begin{tabular}{|c|c|}
\hline Business structure & Quantity $/ \%$ \\
\hline $\begin{array}{c}\text { Economically active private entrepreneurs and } \\
\text { commercial societies }\end{array}$ & 93775 \\
\hline Including: & $86,2 \%$ \\
\hline Microenterprises & $11,2 \%$ \\
\hline small enterprises & $2,3 \%$ \\
\hline medium-sized enterprises & $0,4 \%$ \\
\hline
\end{tabular}

The table is constituted by the author according to Uzṇēmējdarbības vide. Ekonomikas ministrija. Riga. 30/11/2015

At least a half of the small and medium-sized enterprises employs from 2 to 5 employees ${ }^{[16]}$. Having made simple arithmetic operations, we have calculated that at least 100 124 thousand people are employed by these enterprises, generally these are employees of microenterprises and private entrepreneurs whose single turnover tax is $9 \%$. In spite of the fact that the employees of microenterprises are included in the 1st and 2nd pension pillars, and work to receive an old-age pension, the amount allocated for social security payments including pension, is rather small to make significant accumulations for comprehensive pension insurance. It is known that the 1 st and 2 nd pension pillars are capable of providing only $40 \%$ of a salary, therefore future pensions of microenterprise employees can be "much thinner" than of other enterprise employees, even if their salaries are identical.

Another explanation is connected with the shadow economy constituting $24 \%$ of GDP in Latvia. In our case this concerns illegal remuneration for work, so-called "salaries in envelopes". According to the different estimates it constitutes from 25 to $60 \%$ of an employee's salary in a private enterprise. The State Revenue Service considers that every third employee fully or partially gets "salaries in envelopes". This situation has lasted for more than twenty years, but the fight against these "envelopes" has not met with success yet. It is obvious, that this factor influences participation of employees and enterprises in private pension funds.

But even more important issue is a question of trust. The research of SEB bank has shown that only $2,9 \%$ of all employees expect to receive a retirement pension in the future, however, they point out that they know little about the future pension and do nothing to change the situation, hoping

15 Uzn̄ēmējdarbības vide. Riga: Ekonomikas ministrija; 2015 Nov 30. Available from:

www.em.gov.lv//v/nozares_politika/nacionala_industriala_politika/uzneme jdarbibas_vide /

${ }_{16}$ Mikro un mazie uzṇēmumi Latvijas ekonomikā ieṇem aizvien nozīmīgāku lomu. Riga: Lursoft; 2013 May 30. Available from: http://blog.lursoft.lv/2013/05/30/lursoft-petijums-mikro-un-mazie-uznemu mi-latvijas-ekonomika-ienem-aizvien-nozimigaku-lomu/ for a miracle. First of all, the wait-and-see policy is connected with the lack of trust in the retirement system in the future. Only $35 \%$ are sure that they will be able to ensure worthy income in old age, and only $18 \%$ of inhabitants have stated that they make retirement accumulations, the other $82 \%$ do not make any accumulations ${ }^{[17]}$.

Experts assume that on a long-term horizon, in a couple of decades, the 1 st and 2 nd pension pillar will provide the average wage earner with about $40 \%$ of his or her previous labour income. However, it is unlikely to save for decent retirement. In fact, demographic and migratory waves will break off all efforts to create the traditional three-pillar pension system.

Because of the adverse demographic situation, with ever increasing frequency, it is talked about inviability of the present retirement system in the Baltic countries. Financier G. Rungainis talks about necessity of fundamental changes in the present social system and refusal from the social tax ${ }^{[18]}$. Associate professor of the University of Vilnius $\mathrm{T}$. Medaiskis also considers that pensions should be considered more widely. If in the country there are few employed people and many pensioners, taxes of the employed people will not be sufficient for decent pensions. Therefore, in order to have a decent old age, people should take care of themselves: to work longer, to retire later, to study all life ${ }^{[19]}$.

\section{New Tendencies on the Labour Market}

But let's return to the world labour market, where another tendency more strongly makes itself felt. The mentioned report of the World Bank says that even today in the world the ratio of employed people and engaged in small or family business is approximately equal, 1,65 billion and 1,5 billion people respectively; and transfer to small business will proceed. For a reason, in the field of economy and social sciences, according to the research of "Thomson Reuters Essential Science Indicators", the subject connected with activity of family business is inside the top ten of the most quoted scientific researches in the world. ${ }^{[20]}$

One more trend is that a universal virtualization of economy and shift in work in favour of more skilled employees demand fewer workers in all spheres of the national economy where wage labour is used ${ }^{[21]}$. Overboard

\footnotetext{
${ }^{17}$ Rudzītis E, Poriņa-Paksāne S, Sauka A. Pensometrs. Riga: SEB; 2015 February.

${ }_{18}$ Rungainis G. Riga as the European regional center is the largest Latvian success. Kapitāls. 2012(9).

${ }_{19}$ Pavuk O. Latvijskie uchenie osparivajut vivodi MVF po bezrabotice. Latvian scientists dispute the findings of the IMF unemployment. Baltic-Course.com [Internet]. 2013 [cited 2013 March 1]. Available from: http://www.baltic-course.com/rus/_analytics/?doc $=71225$

${ }^{20}$ King C, Pendlebury D. A. Web of knowledge. Research fronts 2013. 100 Top-Ranked Specialties in Science and Social Science. Thomson Reuters. [Internet]. 2013 [cited 2014 Jan 3]. Available from: http://img.en25.com/Web/ThomsonReutersScience/1002571.pdf

${ }^{21}$ Pavuk O. Bitva za ljudskie resursi v Latvii vstupaet v novuju fazu. The battle for human resources in Latvia is entering a new phase. Baltic-Course.com [Internet]. 2011 [cited 2011 Apr 18]. Available from:
} 
there are a great number of unskilled workers who were until recently called the hegemon, a driving force of economy. The unemployment, whose growth was until recently explained by the world crisis, does not decrease and remains even in the developed countries at the level of 10 and more percent. On the labour market the shortage of engineering specialties is far more acute. In the recent world top 20 of the most demanded professions prepared by BBC analysts, only one profession (a psychologist) is related to humanists. Engineers, IT experts, health professionals are waited in different countries of the world and promised decent remuneration for work ${ }^{[22]}$.

It is enough to remind that the ratio of production branches and service trade in world economy changed long ago in favour of the last one, and it is $20 / 80$. But at once there is a problem of collecting the social tax from employees and business, which the state retirement pensions are paid from. Treasury reimbursement is not promoted by such widespread in many countries form of business as microenterprises which pay only one tax, i.e. the turnover tax. For example, in Latvia it is $9 \%$, in Lithuania - $6 \%$ (in Estonia such a form of business does not exist). Such enterprises pop up like mushrooms after a spring rain and enable the people who have been forced out of the labour market to make a living, and that is good. But the reverse side of the coin is decrease in contributions to the system of the government social security funds as microenterprises cannot cover expenses of social security expenditures of their employees.

In such a situation in many countries, including the Baltic ones, the mood of meaninglessness to pay the social tax distinctly makes itself felt, especially among the young population, like "in any case by the time of retirement the system will have ceased to work". With ever increasing frequency we hear appeals to be engaged in savings for an old age, including through the insurance system or private pension funds. Probably, it is a way out of the stalemate situation. But what to do with other segments of the population which need social support, i.e. disabled people, orphans, children from the broken families ... There are more questions than answers.

But how to resolve the global problem, i.e. the youth employment? One of solutions could be a paradoxical decision to lower retirement age, to enable people, if they do not want or cannot work, to retire earlier. It is quite likely that the government will be forced to abandon the state retirement pensions for the majority of able-bodied population, having kept private pension funds.

At the same time it is necessary to carry out the policy of early youth employment: to change the educational system at schools by reducing terms of learning and having entered professional training in the most demanded professions in

http://www.baltic-course.com/rus/opinion/?doc $=40187$

${ }^{22} 20$ samih nuzhnif professij v mire. 20 most desired professions in the world. BBC Russia [Internet]. 2014 [cited 2014 Jan 20]. Available from: http://www.bbc.co.uk/russian/business/2013/04/130326_wanted_migrants clickable.shtml the senior classes and colleges; to encourage university study alongside employment in order to introduce the youth to the labour market as soon as possible, because, as we have mentioned before, shift in work has sharply changed, so sooner or later it is necessary to revolutionise the educational system as well.

The introduction of the unconditional basic income since 2017 for all residents in Finland, discussion of this innovation in Germany, Switzerland and the Netherlands is also possible to consider as a step towards the change of social policy in the European countries ${ }^{[23]}$.

More and more professions demand computer skills and ability to work with other equipment which can appear in the future. Today it is clear that usual education, i.e. school higher education institution, has become a thing of the past. In the fast-changing world it is necessary to study throughout all life. The winners have got not one but some professions or specialties. Such approach will surely bear fruit. The youth will be ranked high on the labour market.

What about the older generation which does not grow old and have the longer performance capability? Those who will wish to continue employment should be enabled to work part-time with probable transfer to another easier work. Flexible work systems, including family business, where people of pre-retirement and retirement age can always be useful, will gain ground.

Economic recovery without the resolution of the unemployment issue, which is directly connected with considerable problems of population ageing, threatens with new political and social fallout. The society needs to change its way of thinking and seriously reflects on self-organisation. The abstract concept of solidarity between generations needs to be filled with a real live sense. It is arguable that the solidarity between generations is shown in the situation when, according to famous anthropologist Mary Catherine Bateson, "people think of the future in the context of the future generations and responsibility for the future which has not been limited to their own life" ${ }^{\text {"24] }}$.

The issues of active ageing of the population have been reflected with highest priority in the Seventh framework programme of EU (FP7), which has become the main source of financing of scientific researches and technological development in Europe. Without social innovations and radical reforming of retirement systems it is impossible to adapt to demographic challenges of a new century.

\section{REFERENCES}

[1] Bateson, M. C. (2011). Composing a Further Life: The Age of Active Wisdom. Knopf Doubleday Publishing Group. P.272.

\footnotetext{
${ }^{23}$ Kirschbaum E. If you were handed $\$ 1,100$ a month, would you amount to anything? Los Angeles Times. 2015.

${ }_{24}$ Bateson M. C. Composing a Further Life: The Age of Active Wisdom. Knopf Doubleday Publishing Group. 2011. p.272.
} 
[2] Modigliani, F. (1970). The life-cycle hypothesis and intercountry differences in the saving ratio in Eltis W. A., Scott M. FG., and Wolfe J. N., eds., Induction, growth, and trade: essays in honour of Sir Roy Harrod, Oxford. Oxford University Press, pp 197-225.

[3] King, C., Pendlebury, D. A. (2013)Web of knowledge. Research fronts 2013. 100 Top-Ranked Specialties in Science and Social Science. Thomson Reuters. P.32. Retrieved: http://img.en25.com/Web/ThomsonReutersScience/1002571. pdf Access: 03.01.2014.

[4] Znotins I. (2006) The prognoses of Latvian residents number and age structure. Demographic trends of Latvia in $21 \mathrm{st}$ century. Commission of Strategic Analysis. Scientific research articles. Riga. Zinante, Volume.3(9), pp. 164.-187.

[5] Latvia. Human Development Report, 2010/2011. National identity, mobility and ability to function. (2011). Riga: Latvian University Faculty of Social and Political Research Institute, p.154.

[6] Latvijas emigrantu kopienas: cerību diaspora. Zinātniskā redaktore I. Mierina. (2015) Latvian emigrant communities: hope diaspora. Scientific editor I. Mieriņa. LU. Rīga. 236. lpp.

[7] United Nations Development Programme. Life Expectancy Index 2014. Retrieved:http://hdr.undp.org/

[8] Pensiju fondu apskats. Komercbanku associācija. (2014) Pension fund overview. Association of Commercial Banks. Riga. Nr. 12, Retrieved: http://lka.org.lv/lv/pdf/PFA_2014_g ads_4_cet.pdf]

[9] Uzṇēmējdarbības vide. Ekonomikas ministrija. (2015) Business environment. Ministry of Economics. Riga. Retrieved: www.em.gov.lv/lv/nozares_politika/nacionala in dustriala politika/uznemejdarbibas_vide/Access:30.11.201 5 .

[10] World Bank. 2012. World Development Report 2013 : Jobs. Washington, DC. (C) World Bank. Retrieved: http://siteresources.worldbank.org/EXTNWDR2013/Resourc es/8258024-1320950747192/8260293-1322665883147/Over view_Russian.pdf Access: 02.01.2013.

[11] World population Data Sheet. 50 Years. 1962 -2012.(2012). Population Reference Bureau. Retrieved: http://www.prb.org /pdf12/2012-population-data-sheet_eng.pdf Access: 03.01 .2013 .

[12] Karalyunayte, U. (2013). Nakopit na dostojnuju starost ne poluchitsja. Karalyunayte, U. (2013) Save up for a worthy old age will not work. Retrieved: http://ru.delfi.lt/news/economy /nakopit-na-dostojnuyu-starost-ne-poluchitsya.d?id=611487 09 Access: 15.04.2013.
[13] Kirschbaum E. If you were handed \$1,100 a month, would you amount to anything? (2015) Los Angeles Times. Retrieved: http://www.latimes.com/world/europe/la-fg-germ any-basic-income-20151227-story.html Access: 27.12.2015.

[14] Mezins I. (2011). Children - Latvian strategic capital. Kapitāls, 02.2011 .

[15] Mikhailov, A. (2013). "Pensionnaja" ekonomika diktuet. Mikhailov, A. (2013). "Pension" economy dictates. On-line newspaper gazeta.ru. Retrieved: http://www.gazeta.ru/colum n/mikhailov/4911557.shtml. Access: 02.01.2013.

[16] Pavuk O. Retirement economy within the context of problems of demography and the labour market in the Baltic States. (2014) // Economic Science for Rural Development, No 36, Jelgava, LLU ESAF, 24-25 April. - P. 110-117. Indexed: AGRIS, EBSCO. Retrieved: http://lufb.llu.lv/conference/ec onomic_science_rural/2014/ESRD_36_2014_Integrated_Sus tainable.pdf

[17] Pavuk O. (2013). Latvijskie uchenie osparivajut vivodi MVF po bezrabotice. Pavuk O. (2013). Latvian scientists dispute the findings of the IMF unemployment. Baltic-Course.com. Retrieved: http://www.baltic-course.com/rus/_analytics/?doc $=71225$ Access: 01.03.2013.

[18] Pavuk O. (2013). Pensionnie fondi Latvii gotovi k perehodu na evro. Pavuk O. (2013). Pension funds in Latvia are ready to adopt the euro. Baltic-Course.com. Retrieved: http://www.baltic-course.com/rus/_analytics/?doc $=73292$ Access: 15.04.2013.

[19] Pavuk O. (2011). Bitva za ljudskie resursi v Latvii vstupaet v novuju fazu. Pavuk O. (2011). The battle for human resources in Latvia is entering a new phase. Baltic-Course.com. Retrieved:http://www.baltic-course.com/rus/opinion/?doc $=4$ 0187 Access: 18.04.2011.

[20] Rudzītis E., Poriņa-Paksāne S., Sauka A. Pensometrs. (2015) SEB. Riga. Februāris.

[21] Rungainis, G. (2012). Riga as the European regional center is the largest Latvian success. Kapitāls, 09/ 2012.

[22] Mikro un mazie uzņēmumi Latvijas ekonomikā ieņem aizvien nozīmīgāku lomu. Micro and small enterprises in the Latvian economy plays an increasingly important role. (2013) Lursoft. Riga. Retrieved: http://blog.lursoft.lv/2013/05/30/lur soft-petijums-mikro-un-mazie-uznemumi-latvijas-ekonomik a-ienem-aizvien-nozimigaku-lomu/ Access: 30.05.2013.

[23] 20 samih nuzhnif professij v mire. 20 most desired professions in the world. (2014). BBC Russia. Retrieved: http://www.bbc.co.uk/russian/business/2013/04/130326 wan ted_migrants_clickable.shtml Access: 20.01.2014. 